\title{
Mexican Bromeliad Weevil (no official common name), Metamasius callizona (Chevrolat) (Insecta: Coleoptera: Curculionidae: Dryophthorinae) ${ }^{1}$
}

\section{Barbra Larson and J. Howard Frank ${ }^{2}$ \\ Introduction and History}

Metamasius callizona (Chevrolat) has no official common name but has been referred to as the "Evil Weevil" by bromeliad enthusiasts throughout Florida, as a result of the destruction it has caused to native populations of bromeliads in the southern portion of the state. A member of the weevil subfamily Rhynchophorinae, it is one of three species of the genus Metamasius present in Florida. Metamasius mosieri Barber, the smallest of the three and native to Florida, Cuba, and the Dominican Republic, has been collected in Florida infrequently. Unlike M. callizona, its presence does not threaten populations of native bromeliads in Florida's natural areas. The third species, Metamasius hemipterus (L.), was first reported in Florida in Miami-Dade County in 1984 and has since become an important pest of sugarcane, bananas, and ornamental palms.

M. callizona, which was first encountered in Florida in 1989 at a Ft. Lauderdale (Broward County) bromeliad nursery, is thought to have entered the state in a shipment of bromeliads imported from Veracruz, Mexico. The nursery was treated, but within two months the weevil was found to be established in northern Broward County and southern Palm Beach County. By 1991 the weevil was present in four counties in southern Florida, and by 1999 it was found in 12 additional counties. As a direct result of attack by M. callizona, the Florida Endangered Plant Advisory Council has added two species of bromeliads (Tillandsia utriculata (L.) and Tillandsia fasciculata Swartz) to the list of endangered species under the 1998 Florida Administrative Code. Additionally, the weevil is approaching the Everglades region, home of Florida's rarest populations of bromeliads.

For more information please see Bromeliad Biota WWW site at: http://bromeliadbiota.ifas.ufl.edu/.

\section{Description}

Adults, which are 11 to $16 \mathrm{~mm}$ (0.4 to 0.6 in.) long, are black with a single yellow or orange band crossing the wing covers above the midpoint. The first and second ventral abdominal segments of males are indented and may display brownish coloration,

1. This document is EENY-161, one of a series of Featured Creatures from the Entomology and Nematology Department, Florida Cooperative Extension Service, Institute of Food and Agricultural Sciences, University of Florida. Published: October 2000. This document is also available on Featured Creatures Website at http://creatures.ifas.ufl.edu. Please visit the EDIS Website at http://edis.ifas.ufl.edu.

2. Barbra Larson and J. Howard Frank, Entomology and Nematology Department, University of Florida, Gainesville, FL.

The Institute of Food and Agricultural Sciences is an equal opportunity/affirmative action employer authorized to provide research, educational information and other services only to individuals and institutions that function without regard to race, color, sex, age, handicap, or national origin. For information on obtaining other extension publications, contact your county Cooperative Extension Service office. Florida Cooperative Extension Service/Institute of Food and Agricultural Sciences/University of Florida/Christine Taylor Waddill, Dean. 


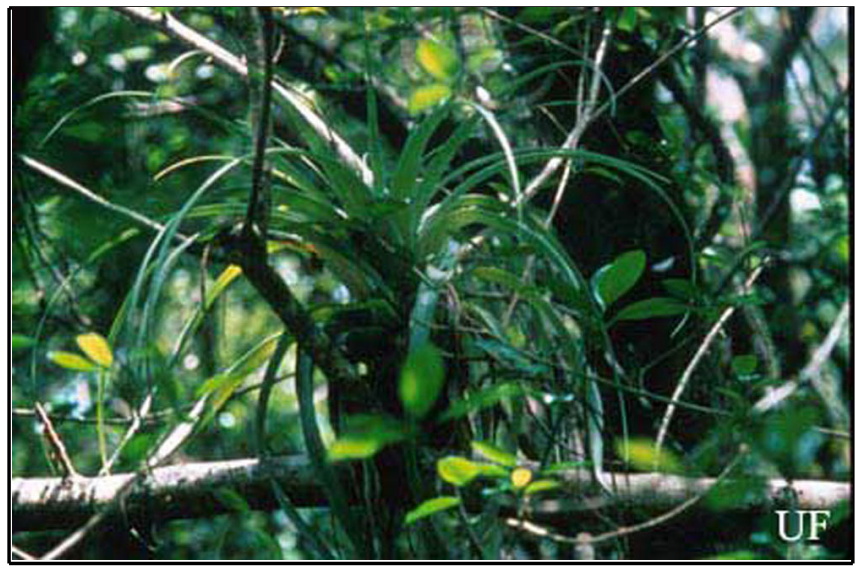

Figure 1. Tillandsia utriculata (L.), a bromeliad species endangered in Florida due to attack by Metamasius callizona (Chevrolat), in the Fakahatchee Strand State Preserve, Collier County, 1993. Credits: H. Nadel, University of Florida

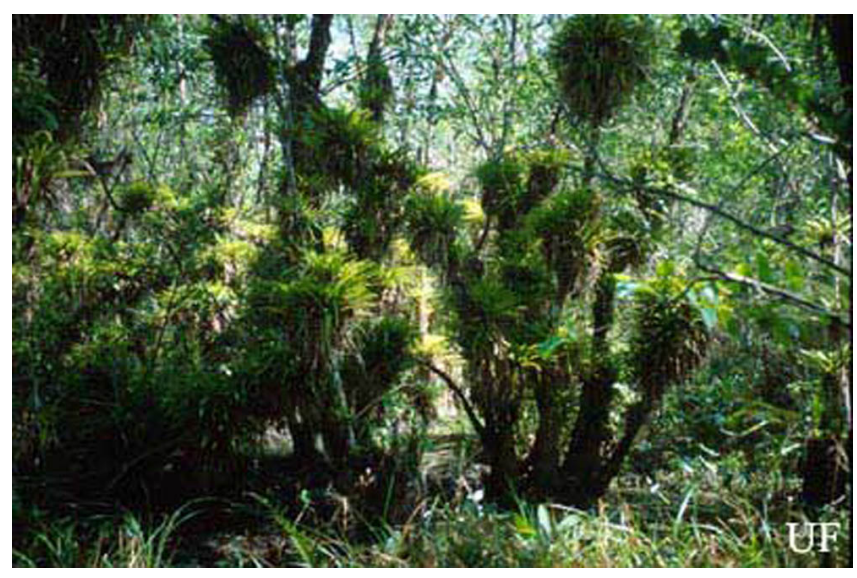

Figure 2. Guzmania monostachia (L.), one of Florida's rare and endangered species of bromeliads, in the Fakahatchee Strand State Preserve, Collier County, 1999. Credits: J.H. Frank, University of Florida

while female abdominal segments are flat and always black.

M. callizona adults are easily distinguished from both $M$. mosieri, which is 6 to $9 \mathrm{~mm}(0.24$ to $0.35 \mathrm{in}$.) long and red and black with two black spots on the upper, red portion of the wing covers, and from $M$. hemipterus, which is 9 to $14 \mathrm{~mm}$ ( 0.35 to $0.55 \mathrm{in}$.) long and may be either red or orange, and black, with variation in color pattern.

\section{M. callizona eggs are elongate, averaging} approximately $2 \mathrm{~mm}(0.08 \mathrm{in}$.) in length and $1 \mathrm{~mm}$ (0.04 in.) in width. They are white when first oviposited, later turning yellow and finally light brown.

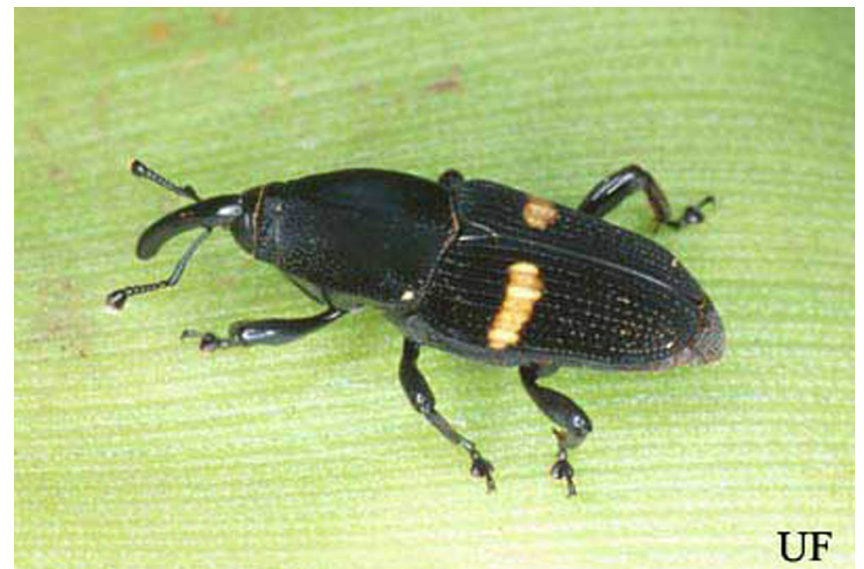

Figure 3. Adult of Metamasius callizona (Chevrolat), the Mexican bromeliad weevil. Credits: J. L. Castner, University of Florida

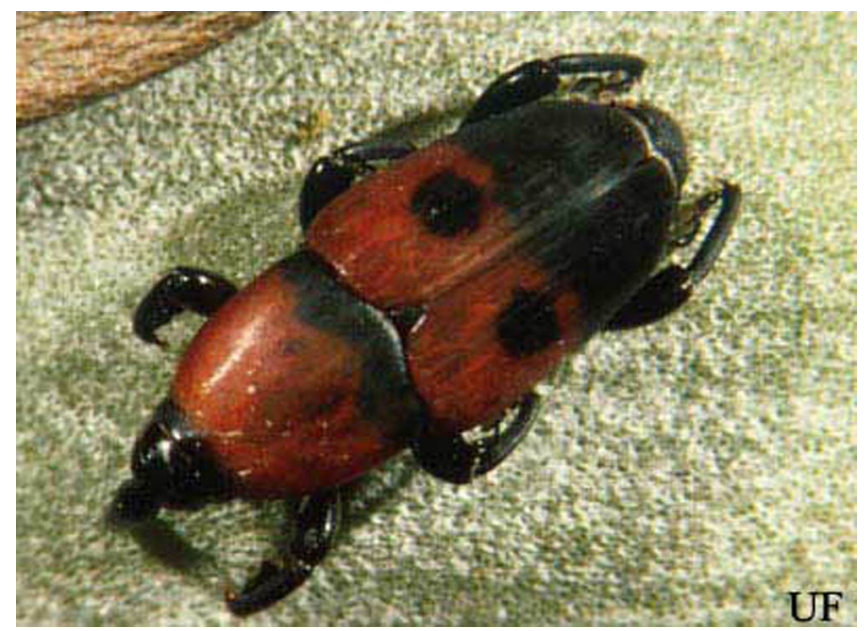

Figure 4. Adult Metamasius mosieri Barber, the Florida bromeliad weevil. Credits: Robin M. Giblin-Davis, University of Florida

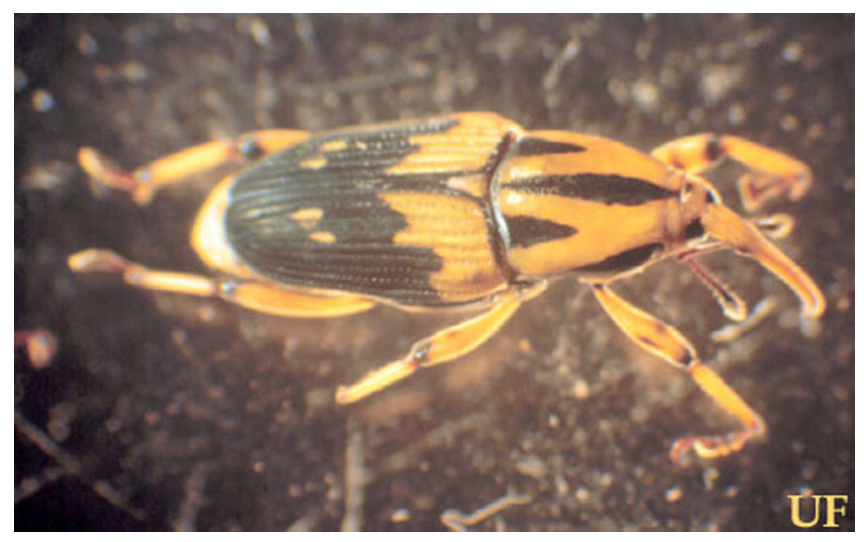

Figure 5. Color pattern of adult Metamasius hemipterus sericeus (Olivier). Credits: Robin M. Giblin-Davis, University of Florida

Larvae are cream-colored with a dark head. Mean head capsule widths for laboratory reared firstthrough fifth-instar larvae were determined to be 0.92 


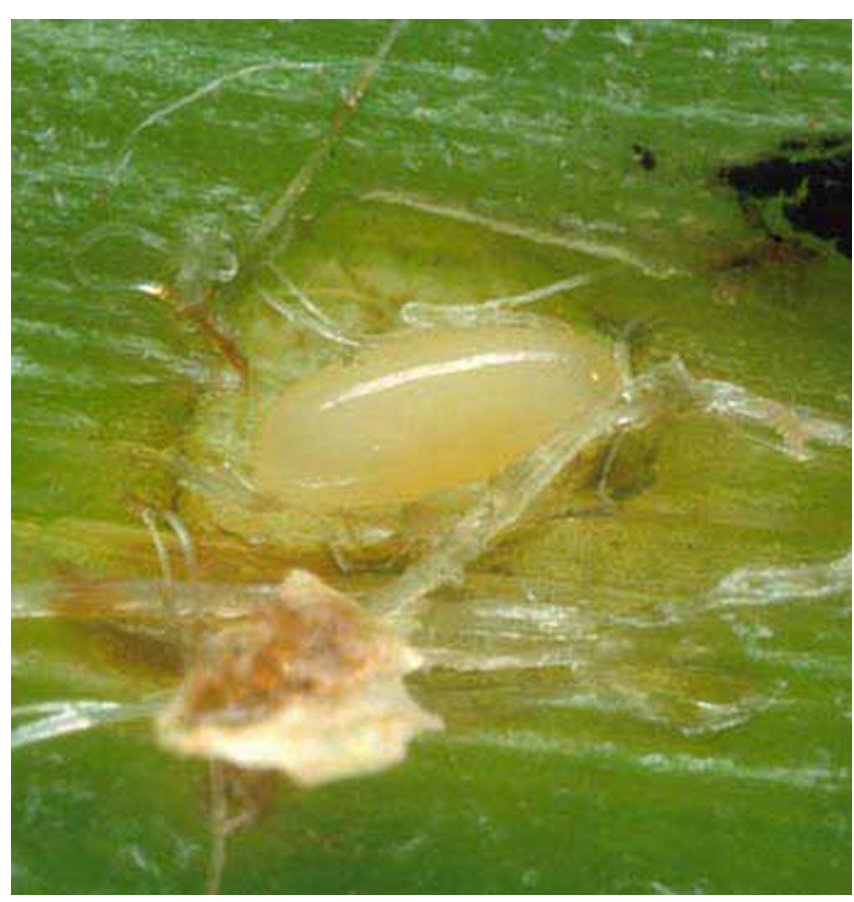

Figure 6. Egg of Metamasius callizona (Chevrolat), the Mexican bromeliad weevil. Credits: J.H. Frank, University of Florida

$\mathrm{mm}$ (0.04 in.), $1.21 \mathrm{~mm}$ (0.05 in.), $1.69 \mathrm{~mm}(0.07$ in.), $2.10 \mathrm{~mm}(0.08 \mathrm{in}$.), and $2.73 \mathrm{~mm}(0.11 \mathrm{in}$.), respectively. While the first three instars have discrete size classes, field-collected fourth- and fifth-instar larvae cannot be distinguished. Pupae are generally found within a fibrous cocoon made of plant material.

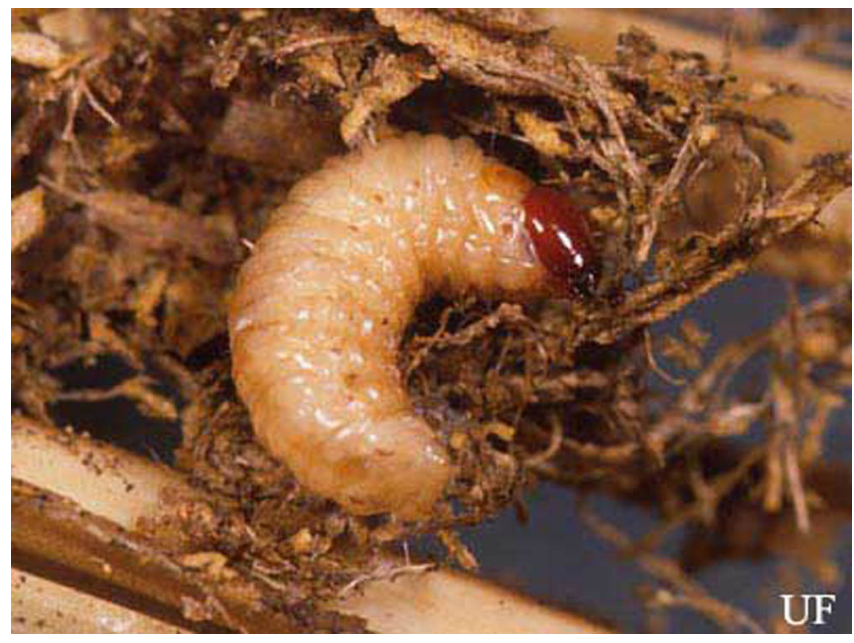

Figure 7. Larva of Metamasius callizona (Chevrolat), the Mexican bromeliad weevil. Credits: J.L. Castner, University of Florida

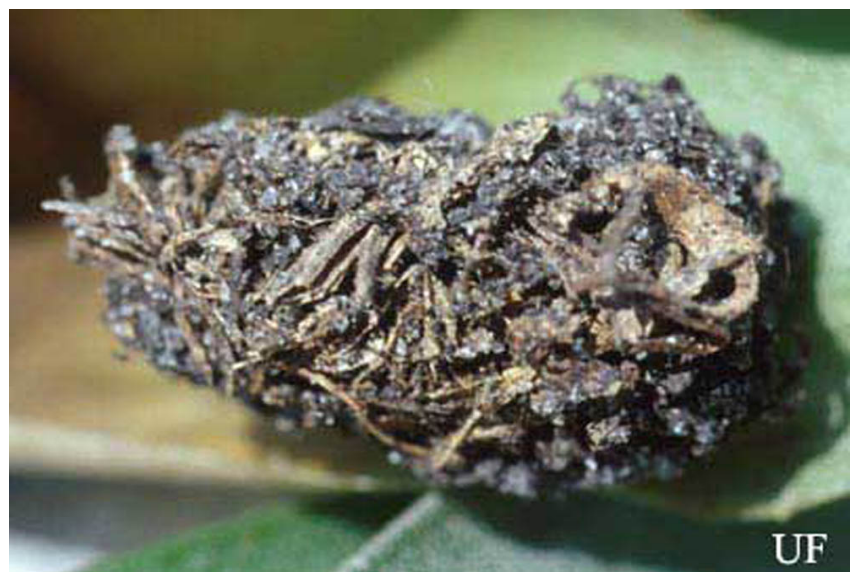

Figure 8. Cocoon of Metamasius callizona (Chevrolat), the Mexican bromeliad weevil, constructed of shredded plant material. Credits: B. Larson, University of Florida

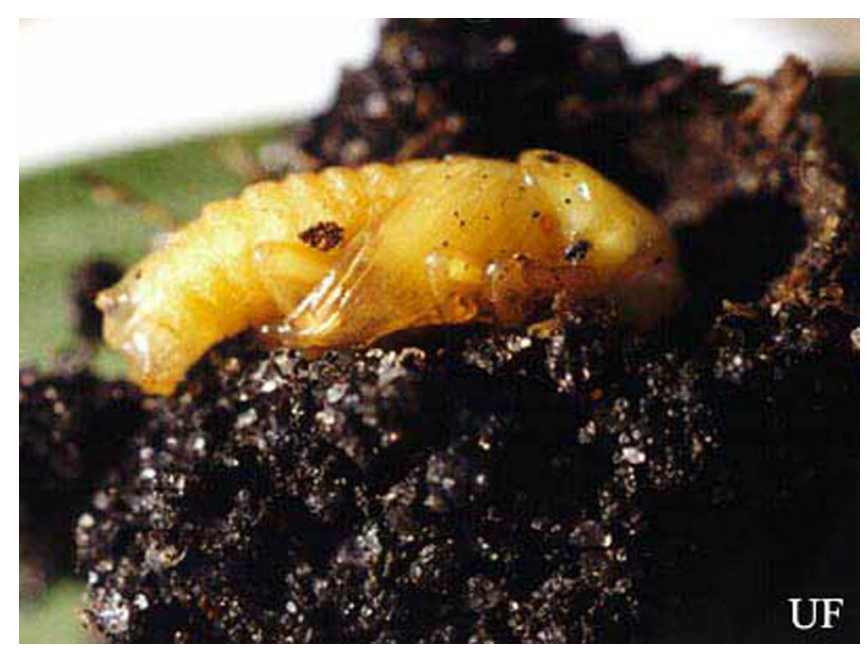

Figure 9. Pupa of Metamasius callizona (Chevrolat), the Mexican bromeliad weevil. Credits: B. Larson, University of Florida

\section{Distribution and Host Plants}

M. callizona was described from Mexico and originally thought to range from Mexico to western Panama, although the report from Panama has been considered questionable. In Mexico, the weevil has been reported on Aechmea mexicana Baker, Catopsis sp. and Tillandsia limbata Schltdl. from Veracruz, on Vriesia sp. from Puebla, on T. utriculata and Tillandsia streptophylla Scheidweiler near Coatepec, on Tillandsia roland-gosselinii Mez near Pochutla, and in a grower's shadehouses near Cordoba on Tillandsia heterophylla Morren, Tillandsia ehlersiana Rauh, T. streptophylla, and Tillandsia deppeana Steudel. Habitats in Mexico where the weevil has been found are often shaded and rainy, over $700 \mathrm{~m}$ in altitude. 
Between 1973 and 1987, USDA-APHIS plant inspectors intercepted 14 weevils determined to be $M$. callizona, being imported primarily on Tillandsia spp. All specimens of $M$. callizona found in imported shipments have originated in Mexico. An additional 122 weevils identified only as Metamasius were intercepted during the same time period on bromeliads known to be attacked by M. callizona .

The weevil is also reported from Guatemala (Alta Verapaz: San Juan). A survey of the Alta Verapaz region in June-August 2000 failed to yield M. callizona, although weevils of related species, principally Metamasius quadrilineatus Champion, were found in bromeliads. Despite the early record of M. callizona from Panama (Chiriquí: Potrerillos), the species was not detected during a survey in 1994. Furthermore, while specimens of many other species of Metamasius are present in the Smithsonian Tropical Research Institute in Panama, there are no M. callizona specimens in the collection, leading to the suggestion that the weevil's natural range does not extend throughout Central America.

The first specimen of M. callizona in Florida was found on a nursery-grown Tillandsia ionantha Planchon, a plant native to Mexico and Central America on which adults will feed but not lay eggs. In natural areas, the weevil primarily attacks $T$. utriculata, T. fasciculata, and Tillandsia paucifolia Baker. The weevil is most damaging to T. utriculata plants, killing them directly. While $T$. fasciculata appears to be more resistant, damage to flowering plants can be highly destructive to their populations. The weevil has also been observed attacking Tillandsia balbisiana Schultes (a species that had been listed already in Florida as threatened) and Tillandsia flexuosa Swartz (already listed as endangered), as well as Catopsis and Guzmania spp. The state's native bromeliads that are likely to be attacked by $M$. callizona if it reaches their more isolated habitats include Tillandsia pruinosa Swartz (endangered), Tillandsia variabilis Schlechtendal (threatened), Guzmania monostachia (L.) (endangered), Catopsis berteroniana (Schultes)(endangered), Catopsis floribunda (Brongniart) (endangered), and Catopsis nutans (Swartz) (endangered). The weevil, which appears to be restricted to plants large enough to supply an adequate amount of stem tissue for larval development, has been found most often in large species of Tillandsia. It will most likely not attack Florida's other native bromeliads (Tillandsia bartramii Elliott, Tillandsia setacea Swartz, Tillandsia simulata Small, Tillandsia recurvata (L.), and Tillandsia usneoides (L.)), which probably do not provide enough plant material for completion of larval development due to their small size.

\section{Florida Native Bromeliads Illustrated WWW site}

Since its first appearance in Broward County, the weevil has spread through much of southern Florida by both natural dispersal and by movement of infested plants. As of December 2000, M. callizona was reported in the following 17 counties in Florida, given with date of first report: Broward (November 1989), Palm Beach (November 1989), Lee (October 1990), Miami-Dade (May 1991), Charlotte (August 1994), St. Lucie (November 1995), Glades (March 1996), Collier (March 1996), Sarasota (August 1996), Manatee (September 1996), Martin (May 1997), Hendry (August 1997), Brevard (November 1998), Indian River (December 1998), Desoto (March 1999), Highlands (March 1999), and Polk (December 2000).

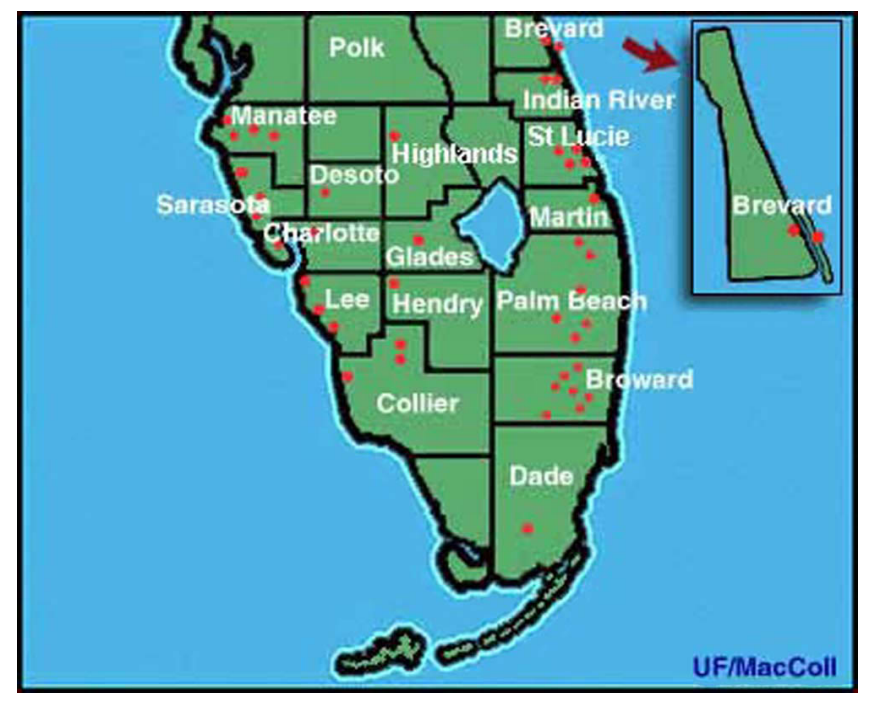

Figure 10. Distribution of M. callizona in Florida. Credits: F. MacColl, University of Florida

In addition to attacking bromeliads in parks and other public lands, the weevil has infested private bromeliad collections and nurseries. Under greenhouse conditions, bromeliads mined and killed by $M$. callizona have included Aechmea cvs., Ananas 
comosus (L.) (pineapple), Canistrum lindenii (Regel)

Mez, Cryptanthus cvs., Dyckia sp., Fernseea bocainensis Pereira \& Moutinho, Guzmania cvs., Hechtia sp., Hohenbergia sp., Neoregelia cvs., Neoregelia compacta (Mez), Nidularium cv., Orthophytum gurkenii Hutch., Pitcairnia angustifolia Solander, Quesnelia "testudo", T. fasciculata, T. paucifolia, T. utriculata, and Vriesia cvs.

\section{Biology and Damage}

When reared on a diet of pineapple stem, the weevil's development time from oviposition to adult emergence averaged approximately eight weeks under laboratory conditions (temperature of 26 degrees $\mathrm{C}$, relative humidity of $82 \%$, photoperiod of 14:10 L:D). Mean duration of the egg stage was 8.3 days, while the larval stage averaged 36.4 days (5.0 days, 4.5 days, 4.4 days, 5.7 days and 17.8 days for the first to fifth larval instars, respectively). The pupal stage lasted a mean of 11.8 days.

Pre-ovipositional period of females is unknown, but minimal generational time in the field is estimated to be 10 weeks, with mean generational time projected to be 13 to 17 weeks. Larvae, pupae and adults have been found throughout the year in southern Florida, suggesting continuous mating. Therefore, there are probably three to four continuous generations per year in Florida.

All life stages of the weevil may be present in the same plant. Adult females, which primarily feed on leaves but have been seen to feed on flowers, cut slits in host plant leaves close to their feeding sites, into which they lay eggs individually. Newly emerged larvae begin to consume leaf tissue as they move down to the base of the stem. They tunnel into the growing stem tissue, producing large holes in the base that may cause the plant to dislodge from its support structure on the tree. Larval damage is generally confined to the base of the plant but can also reach up the flower stalk. Several weevils may successfully develop on the same host plant, provided there is sufficient plant tissue. However, larger larvae will attack smaller ones upon encountering them. The weevil usually pupates in the center of the plant's stem, within a cocoon it constructs from shredded plant material. When reared in planted pineapple tops, the weevil sometimes pupates in the soil near the base of the plant.

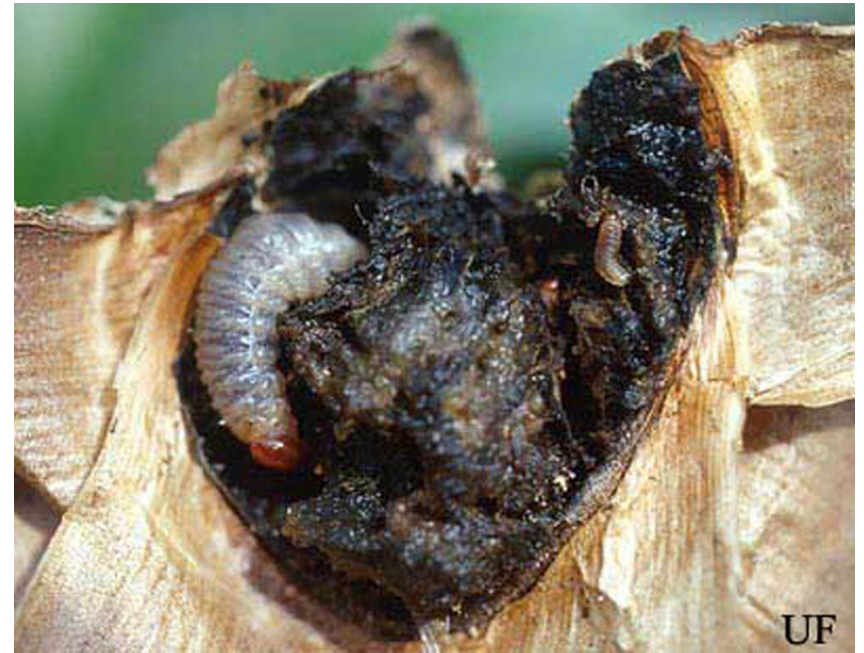

Figure 11. Three larvae of Metamasius callizona (Chevrolat), the Mexican bromeliad weevil, destroying base of Tillandsia utriculata (L.) stem. Credits: F. MacColl, University of Florida

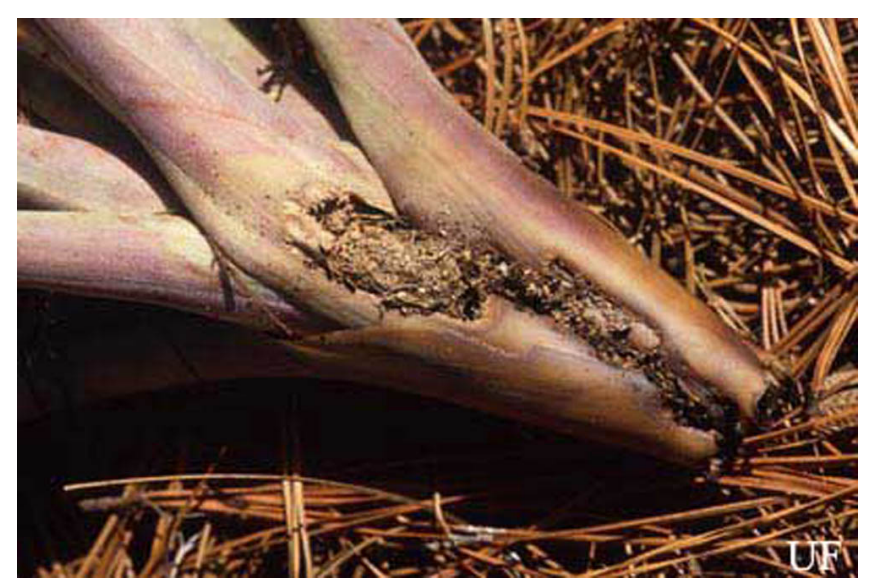

Figure 12. Stem of Tillandsia utriculata (L.), damaged by Metamasius callizona (Chevrolat), the Mexican bromeliad weevil, with weevil cocoon. Credits: J.L. Castner, University of Florida

Damage is often accompanied by the production of a light brown, gelatinous material, which may be the plant's defensive reaction. This gel can be seen covering entrance holes to the weevil mines. Other symptoms of weevil damage include adult feeding marks on leaves, browning of leaves, and decomposition of the base of the central leaves, which can easily be pulled out when larval mining is significant.

In ornamental bromeliad nurseries, the mining of M. callizona larvae directly kills some species. Extent of damage to natural bromeliad populations in Florida varies. For example, heavy infestations of large, flowering plants have caused severe damage to 


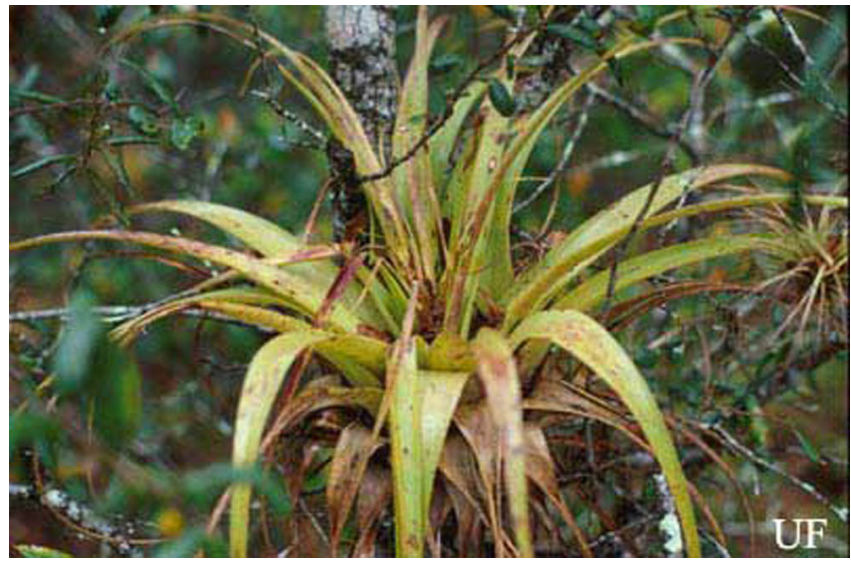

Figure 13. Damage on leaves of Tillandsia utriculata (L.) by Metamasius callizona (Chevrolat), the Mexican bromeliad weevil. Credits: J.H. Frank, University of Florida

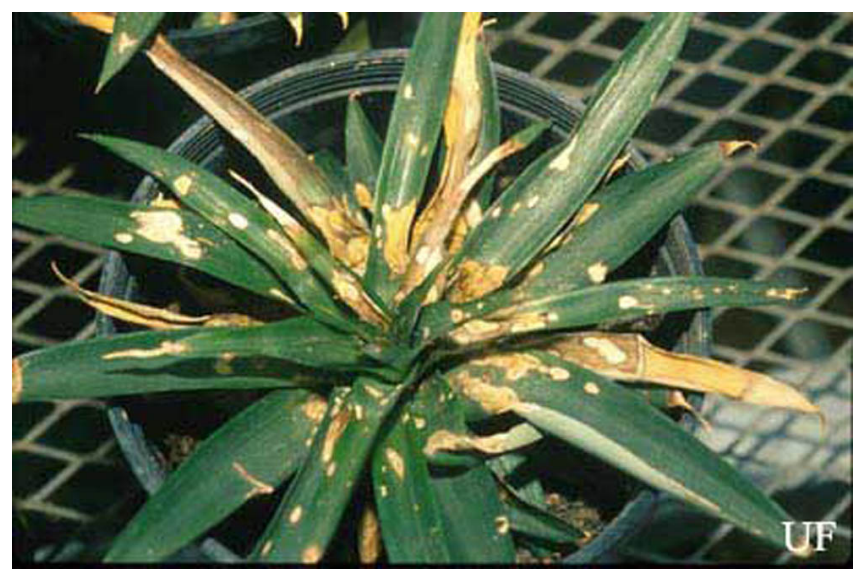

Figure 14. Damage on leaves of pineapple, Ananas comosus (L.), by Metamasius callizona (Chevrolat), the Mexican bromeliad weevil. Credits: P.M. Choate, University of Florida

populations of T. utriculata, which reproduces primarily by seed. T. fasciculata plants are able to produce offsets, which aids their populations to some extent in escaping decimation by the weevil. However, the absence of any natural enemies of the weevil in Florida has resulted in much greater destruction to bromeliad populations than that occurring in any part of the weevil's natural range.

\section{Management}

Where infestations of $M$. callizona occur on ornamental bromeliads grown in nurseries, a reduced concentration of an insecticide labeled for beetle adults and grubs is recommended, applied as a spray or dip every two to three months to prevent infestations. This recommendation is based on general principles and not on specific efficacy data, since no chemical trials of any pesticide have been carried out against the weevil.

Insect Management Guide for Ornamentals [see Beetles]

Landscape Plant Insect Management Suggestions

In natural areas, where the pest is threatening native populations of bromeliads, chemical control is not feasible, in part because the epiphytic growth habit of the host plants makes them inaccessible from the ground. More importantly, many of the populations affected by the pest are found in state and county parks, where use of chemical pesticides is not acceptable because of possible effects on non-target organisms.

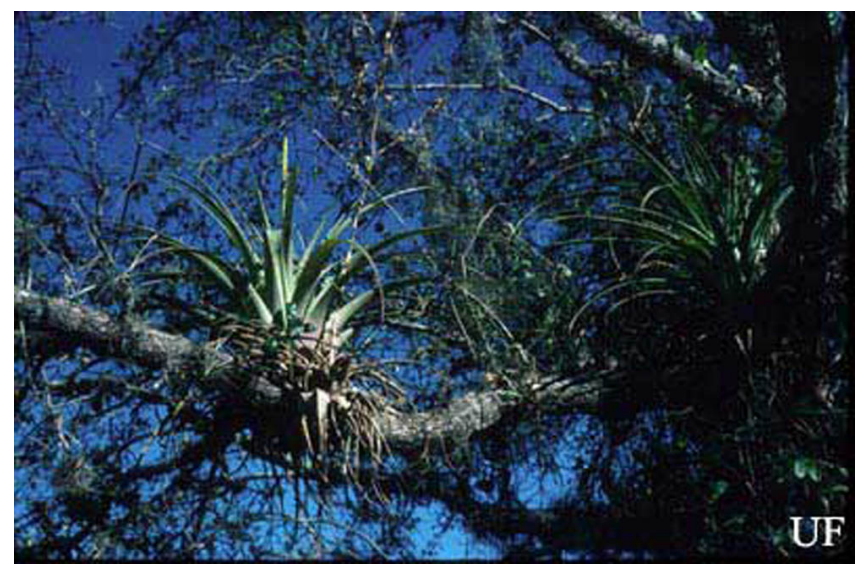

Figure 15. Bromeliads anchored to tree branches, Miami-Dade County, 1996. Credits: J.H. Frank, University of Florida

Biological control offers the most likely success in management of the weevil. One potential biological control agent was discovered and studied at the Escuela Agrícola Panamericana in Zamorano, Honduras. This parasitoid tachinid fly of the genus Admontia was found attacking the closely related weevil species M. quadrilineatus in Honduran cloud forests, primarily in species of Tillandsia. The female fly larviposits at the base of leaves, near the entrance to the tunnel made by weevil larvae, and the fly larvae enter the tunnel to seek out the host. Fly larvae attack the larval stage of the weevil, and while parasitized weevil larvae may construct a pupation chamber, they die before pupating. Percent parasitism of weevils in field-collected bromeliads in Honduras has ranged from 5 to $67 \%$ and seems to increase 
during the summer rainy season to reach a maximum in October-November.

Admontia flies brought into Florida and maintained in a quarantine facility have been found to parasitize $M$. callizona in bromeliad plants. Once a fly colony can be established, host testing on related weevil species must be carried out before the flies can be mass-produced and released at sites of high weevil populations. It is hoped that fly populations can be established in those areas to suppress populations of M. callizona.

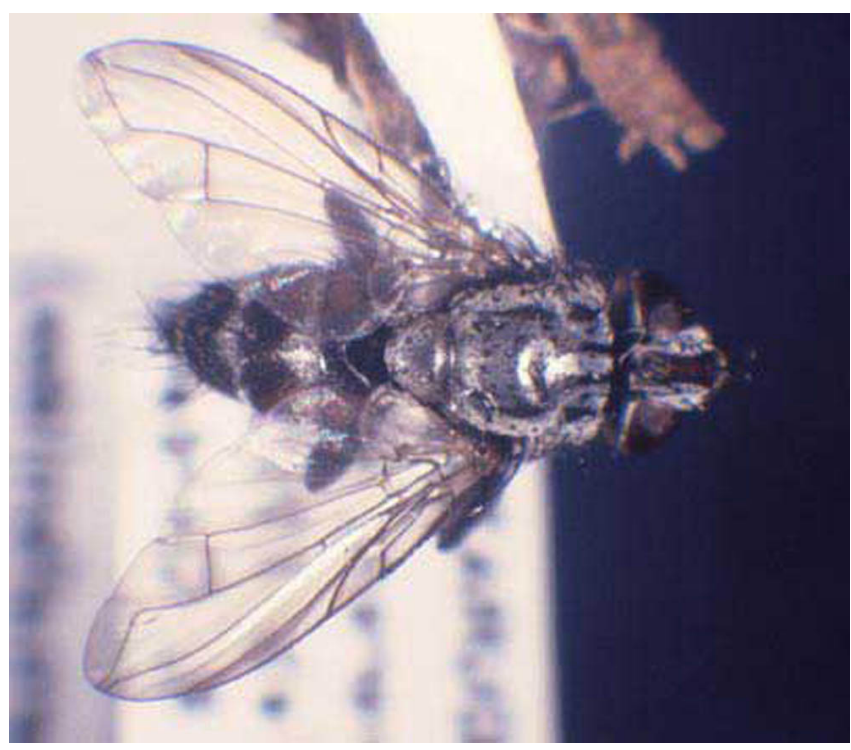

Figure 16. Dorsal view of adult of Admontia sp., a parasitic fly of Metamasius callizona (Chevrolat), the Mexican bromeliad weevil. Credits: R. Cave, Escuela Agrcola Panamericana

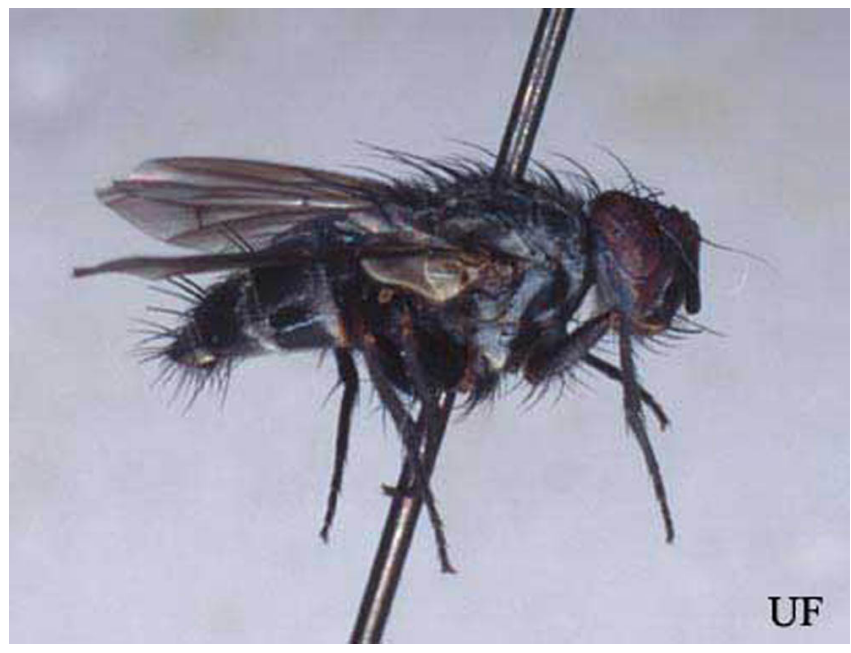

Figure 17. Lateral view of adult of Admontia sp., a parasitic fly of Metamasius callizona (Chevrolat), the Mexican bromeliad weevil. Credits: P.M. Choate, University of Florida
The Florida Council of Bromeliad Societies (FCBS) has initiated a project to collect seed of native bromeliads threatened by $M$. callizona. Plants grown from those seeds will eventually be replaced in their natural setting if weevil populations are successfully reduced. For more information on the seed collection project and biological control efforts, see the Save Florida's Native Bromeliads" Project WWW site.

At least 20 other species of weevils are known to attack bromeliads in Central and South America. Several related species of weevils have been found in shipments of bromeliads from neotropical countries, including Metamasius flavopictus (Champion), Metamasius sellatus Champion, and $M$. quadrilineatus. Therefore, in addition to managing populations of $M$. callizona already present in the state, it is necessary to prevent the accidental importation of additional weevil pests. There are two important preventive tactics. Dipping imported plants in insecticides labeled for beetles both before leaving the country of export and after arriving in Florida reduces the risk, although the effect of chemicals on eggs is unknown. However, the most effective preventive tactic is to import only seeds of neotropical bromeliads.

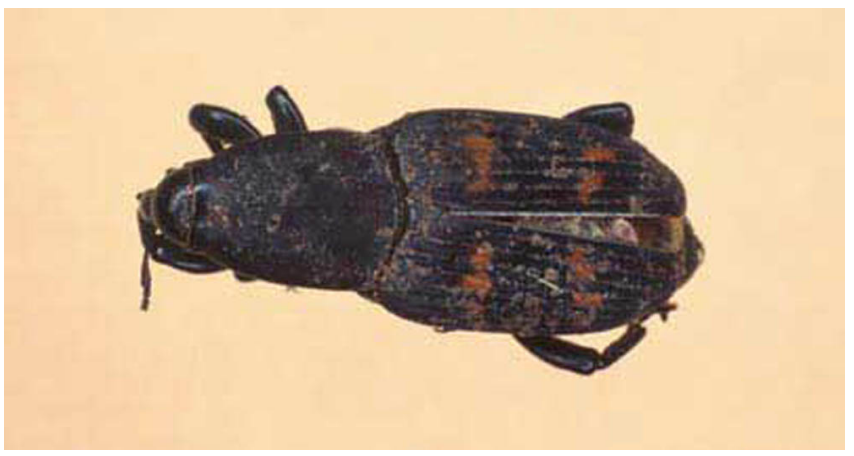

Figure 18. Adult Metamasius flavopictus (Champion), a weevil pest of bromeliads. Credits: J. Lotz, Division of Plant Industry

\section{Selected References}

Cave, R.D. 1997. Admontia sp., a potential biological control agent of Metamasius callizona in Florida. Journal of the Bromeliad Society 47:244-249. 


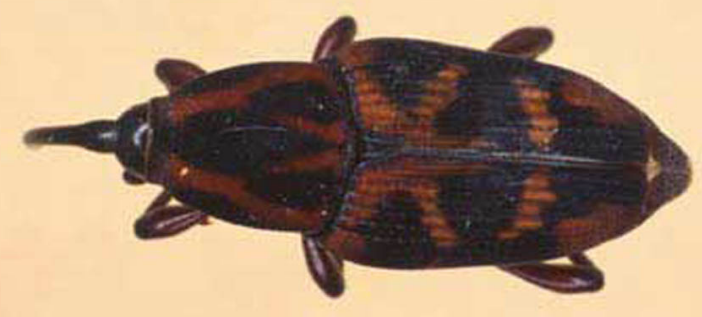

Figure 19. Adult Metamasius sellatus Champion, a weevil pest of bromeliads. Credits: J. Lotz, Division of Plant Industry

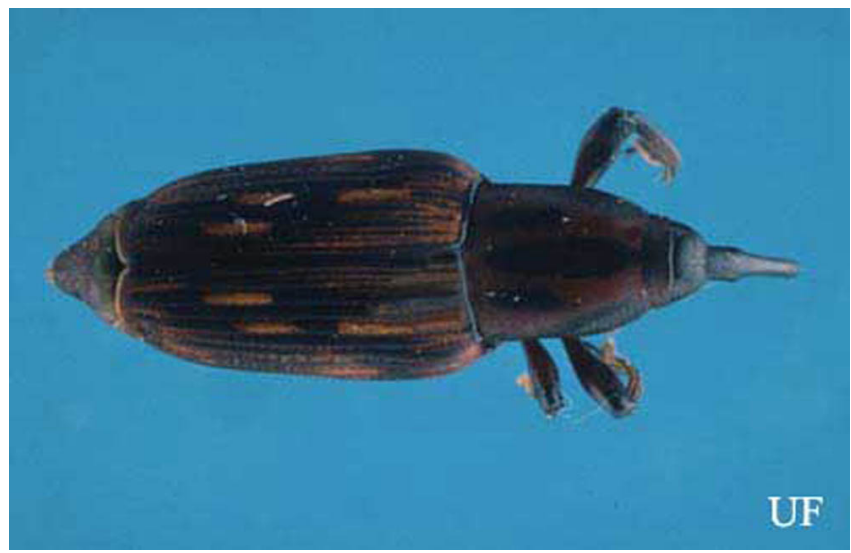

Figure 20. Adult Metamasius quadrilineatus Champion, a weevil pest of bromeliads. Credits: J.H. Frank, University of Florida

Creel, O.R. 2000. The evil weevil: what will Florida lose? The Palmetto 19:10-11,14-16.

http://fcbs.org/articles/weevil-creel.htm (June 2001)

Frank, J.H. 1997. Protection of Florida's native bromeliads by control of Metamasius callizona. Journal of the Bromeliad Society 47:60-64.

Frank, J.H. 1999. Bromeliad-eating weevils. Selbyana 20:40-48.

Frank, J.H. 1999. Further spread of the weevil Metamasius callizona in Florida. Journal of the Bromeliad Society 49:206-209.

Frank, J.H. 2000. Florida's native bromeliads imperiled by exotic evil weevil. The Palmetto 19:6-9,12.

Frank, J.H. and M.C. Thomas. (September 2000). Weevils that eat bromeliads. http://bromeliadbiota.ifas.ufl.edu/wvbrom.htm (20 September 2000).

Frank, J.H. and M.C. Thomas 1994. Metamasius callizona (Chevrolat) (Coleoptera: Curculionidae), an immigrant pest, destroys bromeliads in Florida. Canadian Entomologist 126:673-682.

O'Brien, C.W. and M.C. Thomas 1990. The species of Metamasius in Florida. Florida Department of Agriculture and Consumer Services, Division of Plant Industry, Entomology Circular 330:1-4.

O'Brien, C.W., M.C. Thomas and J.H. Frank 1990. A new weevil pest of Tillandsia in south Florida. Journal of the Bromeliad Society 40:203-205, 222.

Salas, J. and J.H. Frank. 2001. Development of Metamasius callizona (Coleoptera: Curculionidae) on pineapple stems. Florida Entomologist 84: 123-126.

Vaurie, P. 1966. A revision of the neotropical genus Metamasius (Coleoptera, Curculionidae, Rhynchophorinae). Species groups I and II. Amer. Mus. Nat. Hist. Bull. 131:213-337. 